\title{
ОСОБЛИВОСТІ ПОСТКОВІДНОГО СИНДРОМУ В ПАЦІЄНТІВ, ЯКІ ПЕРЕНЕСЛИ COVID-19: ВПЛИВ НА СЕРЦЕВО-СУДИННУ СИСТЕМУ
}

Особливості постковідного синдрому в пацієнтів, які перенесли COVID-19: вплив на серцево-судинну систему

\section{Т. М. Гомелюк, Д. В. Попович, М. І. Марущак}

Тернопільський національний медичний університет імені І. Я. Горбачевського МОЗ України

Резюме. На початку пандемії вважалося, що COVID-19 - че короткотривала хвороба. Однак уже влітку 2020 р. Всесвітня організація охорони здоров'я, використовуючи наявні на той час дані, повідомила, що у деяких пацієнтів симптоми виснаження зберігаються тижнями або, навіть, місяцями. Клінічні дослідження пацієнтів, інфрікованих SARS-CoV-2, засвідчили ураження багатьох органів або систем, включаючи легені, мозок, нирки та серцево-судинну систему. Незважаючи на величезні дослідження серцево-судинних ускладнень COVID-19 та його механізмів, ряд питань, які не мають відповіді, залишаються невирішеними. Проте варто відмітити, що дослідження також мають визначити цільову групу, терміни скринінгу після первинного одужання від COVID-19 та тести, які допоможуть у сортуванні осіб, які знаходяться в групі ризику.

Мета досліджння - проаналізувати сучасні літературні джерела про постковідний синдром у хворих із коморбідним перебігом COVID-19 та серцево-судинною патологією.

Матеріали і методи. У дослідженні опрацьовано наукові публікації за останні роки, які доступні у мережі «lнтернет», ключовими словами були: «COVID-19», «SARS-CoV-2», «постковідний синдром», «серцево-судинна патологія».

Результати. Наявність серцево-судинного захворювання збільшує смертність у пацієнтів із COVID-19, а серцево-судинні ушкодження, включаючи міокардит, порушення серцевого ритму, ураження ендотеліальних клітин, тромботичні явища та інтерстиціальний фріброз міокарда, синдром постуральної ортостатичної тахікардії, спостерігаються в окремих пацієнтів, які перенесли COVID-19. Основна патофізіологія серцево-судинних ускладнень, пов'язаних з COVID-19, до кінця не вивчена, хоча пряма вірусна інфрекція міокарда та цитокіновий шторм були запропоновані як можливі механізми.

Висновки. Результати аналізу літературних джерел обґрунтовують актуальність дослідження постковідного синдрому в пацієнтів із коморбідним перебігом COVID-19 та серцево-судинною патологією.
Features of post-COVID syndrome in patients who had COVID-19: effects on the cardiovascular system

T. M. Homeliuk, D. V. Popovych, M. I. Marushchak

I. Horbachevsky Ternopil National Medical University

e-mail: gomelyuk_tmyh@tdmu.edu.ua

Summary. At the beginning of the pandemic, COVID-19 was thought to be a short-lived disease. However, in the summer of 2020, the World Health Organization, using available data at the time, reported that some patients had symptoms of exhaustion for weeks or even months. Clinical studies of patients infected with SARS-CoV-2 have shown damage to many organs or systems, including the lungs, brain, kidneys and cardiovascular system. Despite extensive research into the cardiovascular complications of COVID-19 and its mechanisms, a number of unanswered questions remain unresolved. However, it is worth noting, that the study should also identify the target group, terms of screening after initial recovery from COVID-19 and tests, which will help in sorting people, who are at risk.

The aim of the study - to analyze modern literature sources on post-COVID syndrome in patients with comorbid COVID-19 and cardiovascular pathology.

Materials and Methods. The study examined the scientific publications of recent years, which are available on the Internet, key words "COVID-19", "SARS-CoV-2", key words "COVID-19","SARS-CoV-2", "post-COVID syndrome", "cardiovascular pathology".

Results. The presence of cardiovascular disease increases mortality in patients with COVID-19 and cardiovascular damage, including myocarditis, cardiac arrhythmias, endothelial cell lesions, thrombotic events and interstitial myocardial fibrosis, postural orthostatic tachycardia syndrome, observed in individual patients who underwent COVID-19. The main pathophysiology of cardiovascular complications associated with COVID-19, not fully studied, although direct myocardial viral infection and cytokine storm have been suggested as possible mechanisms.

Conclusions. The analysis of literature sources substantiates the relevance of the study of post-COVID syndrome in patients with comorbid course of COVID-19 and cardiovascular disease. Defining the role of COVID-19 in the development and progression of cardiovascular disease will pave the way for new approaches to the diagnosis, 
Визначення ролі COVID-19 у розвитку і прогресуванні серцево-судинних захворювань відкриє шлях для нових підходів до діагностики, стратифрікації, моніторингу, профрілактики та лікування цього захворювання.

Ключові слова: COVID-19; постковідний синдром; серцево-судинна патологія.

\section{ВСТУП}

Коронавірусна хвороба 2019 р. (COVID-19), спричинена іноекцією від тяжкого гострого респіраторного синдрому коронавірусу (SARS-CoV-2), поширилася у світі як серйозна пандемія. SARS-CoV-2, оболонковий вірус із несегментованим, одноланцюговим геномом позитивної РНК, є членом сімейства Coronaviridae (CoV), який викликає переважно респіраторні захворювання з широким діапазоном клінічної тяжкості, починаючи від безсимптомного або слабосимптомного (лихоманка, кашель, задишка, міалгії, втома та діарея) у значної частини пацієнтів до тяжкого гострого респіраторного дистрес-синдрому (ГРДС) та фратальної поліорганної недостатності [1].

Захворювання має рівень летального результату, який коливається від менше ніж 0,5 до понад 7 \% (у середньому 3,8 \%), при цьому інфеекційність вища, ніж при грипі. Його висока передача та відносно висока частота серйозних ускладнень призвели до того, що COVID-19 став серйозною загрозою для здоров'я населення у всьому світі.

COVID-19 визнано поліорганним захворюванням із широким спектром проявів. Подібно до постгострих вірусних синдромів, описаних у людей, які пережили інші вірусні епідемії коронавірусу, все більше повідомлень про стійкі та тривалі наслідки після перенесеного COVID-19. Наукові та клінічні дані розвиваються щодо підгострих і довгострокових наслідків COVID-19, який може вражати різні системи органів. Ранні звіти свідчать про залишкові явища інфекції SARS-CoV-2 [2]. Ці постійні симптоми можна класифрікувати як серцево-легеневі (біль у грудях, серцебиття, тахікардія та задишка), неврологічні (невропатія, мієлопатія, когнітивні порушення, головний біль, дисгевзія та аносмія або паросмія), психічні розлади (депресія, тривожні розлади та порушення сну) або неспецифічні (втома, біль у суглобах та м'язова слабкість). Ушкодження клітин, сильна вроджена імунна відповідь із виробленням запальних цитокінів та стан прокоагуляції, спричинений інфекцією SARS-CoV-2, можуть сприяти виникненню цих наслідків. Люди, які перенесли попередні коронавірусні інсрекції, включаючи епідемію SARS у 2003 р. та спалах респіраторного синдрому на Близькому Сході (MERS) у 2012 р., продемонстрували подібні стійкі симптоми, що stratification, monitoring, prevention and treatment of this disease.

Key words: COVID-19; post-COVID syndrome; cardiovascular pathology.

посилюють занепокоєння щодо клінічно значущих результатів даного захворювання.[3]

Мета дослідження - проаналізувати сучасні літературні джерела про постковідний синдром у хворих із коморбідним перебігом COVID-19 та серцево-судинною патологією.

\section{МАТЕРІАЛИ I МЕТОДИ}

У дослідженні опрацьовано наукові публікації за останні роки, які доступні у мережі «Інтернет», ключовими словами були: «COVID-19», «SARSCoV-2», «постковідний синдром», «серцево-судинна патологія».

\section{РЕЗУЛЬТАТИ Й ОБГОВОРЕННЯ}

Систематичне вивчення наслідків після одужання від гострого COVID-19 необхідне для розробки багатопрофрільного командного підходу, заснованого на доказах, з догляду за цими пацієнтами та визначення пріоритетів досліджень. Всебічне розуміння потреб у догляді за пацієнтами після гострої фрази допоможе у розвитку інфрраструктури клінік COVID-19, які будуть обладнані для надання комплексної багатопрофрільної допомоги в амбулаторних умовах. Незважаючи на те, що визначення термінів після гострого COVID-19 розвивається, було запропоновано включати збереження симптомів або розвиток наслідків понад 3 або 4 тижні від початку гострих симптомів COVID-19, оскільки здатний до реплікації SARS-CoV-2 не був виділений через Зтижні. Для цілей цього огляду ми визначили пост-гострий COVID-19 як стійкі симптоми або перенесені чи довгострокові ускладнення інфекції SARS-CoV-2 понад 4 тижні від початку симптомів. На основі нещодавньої літератури він також поділяється на дві категорії:

- підгострий або триваючий симптоматичний COVID-19, який включає симптоми та відхилення від норми протягом 4-12 тижнів після гострого COVID-19;

- хронічний або пост-COVID-19-синдром, який включає симптоми та відхилення, що зберігаються або присутні більше 12 тижнів від початку гострого COVID-19 і не пов'язані з альтернативними діагнозами $[4,5]$.

Нова коронавірусна хвороба (COVID-19), спричинена тяжким гострим респіраторним синдромом
Вісник медичних і біологічних досліджень Bulletin of Medical and Biological Research
$4(10), 2021$ 
коронавірусу-2 (SARS-CoV-2), вражає організм людини загалом та органи й системи зокрема. Однак серцево-судинні наслідки інфрекції є значущими, особливо з огляду на їх внесок у захворюваність і смертність. Розуміння патогенезу, у свою чергу, допоможе проведенню ефективного лікування та реабілітації пацієнтів. На сьогодні точний механізм залучення серцево-судинної системи при COVID-19 ще не зовсім зрозумілий, проте є дані, що клітини, які експресують рецептори ангіотензинперетворювального ферменту-2 (АПФ-2), потенційно схильні до ризику інфікування SARS-CoV-2. АПФ-2, виступаючи рецептором коронавірусів SARS-CoV-2 та SARS-CoV, є ключовою ланкою ренін-ангіотензинової системи, що робить внесок у патофрізіологію захворювань серцево-судинної, ендокринної, видільної систем. АПФ-2, що в нормі діє як протеаза для розщеплення ангіотензину-ІІ, підтримує показники артеріального тиску, частоти серцевих скорочень й осмотичного тиску. Плейотропні ефректи гена АПФ-2 актуалізують аналіз накопичених генетичних і епідеміологічних даних щодо SARSCoV-2, COVID-19 і мультифакторіальних патологій людини [6]. Отже, у пацієнтів із високим ризиком розвитку серцево-судинних захворювань втрата АПФ-2 у результаті інтерналізації рецепторів, викликаної SARS-CoV-2, загострить серцево-судинні захворювання (СС3). Найчастішими серцево-судинними ускладненнями COVID-19 є гостре ураження міокарда, міокардит, інфраркт міокарда, серцева недостатність, кардіоміопатія, аритмії та венозні тромбоемболічні явища. Крім того, наявні серцево-судинні захворювання у пацієнтів із COVID-19 є основним маркером розвитку тяжкого захворювання і пов'язані з високим рівнем смертності.

Серед різноманітних фрізіологічних наслідків тяжкої форми COVID-19 серцево-судинні ускладнення виявилися одними 3 найбільш значущих і небезпечних для життя. COVID-19 може проявлятися дихальною недостатністю внаслідок пневмонії та ГРДС, із розподільним кардіогенним шоком або без нього, а також тяжким ураженням серця, що проявляється у вигляді помітного підвищення рівня тропоніну та серцевої недостатності [7]. Ураження серця також пов'язують із підвищенням смертності. У когортному дослідженні 416 пацієнтів із підтвердженим COVID-19 підвищений рівень тропоніну був присутній у 19,7 \% пацієнтів під час госпіталізації і був визнаний незалежним фактором ризику внутрішньолікарняної смертності. Підвищена частота серцевих ушкоджень серед людей із тяжкими синдромами системної запальної реакції та шоком в умовах COVID-19 також підкреслює важливий зв'язок між імунною відповіддю на вірус та серцево-судинною системою. Крім того, було відзначено високу поширеність наявних серцево-метаболічних захворювань серед людей із тяжким перебігом
COVID-19 , а ті, у кого вже існують серцево-судинні захворювання, мають підвищену смертність під час інорекції COVID-19 [8]. Зокрема, зареєстровані показники смертності від COVID-19 становлять 10,5 \% у пацієнтів із серцево-судинними захворюваннями, 7,3 \% в осіб із цукровим діабетом та 6,0 \% у пацієнтів із гіпертонією [9].

Результати спостереження показали, що велика кількість хворих, які перенесли COVID-19, повторно звертаються за медичною допомогою зі скаргами, які характерні для ураження кардіоваскулярної систем. Найчастішим персистуючим симптомом $€$ задишка, яка, ймовірно, має багатофракторну етіологію. Хоча ми зосереджуємось на серцево-судинних ускладненнях, вплив COVID-19 на дихальну фрункцію, безсумнівно, сприяє виникненню задишки, що спостерігається у цих пацієнтів. Біль у грудях $€$ найпоширенішим постійним серцево-судинним симптомом у пацієнтів, які перенесли COVID-19. В одному дослідженні повідомлялося про біль у грудній клітці у $18 \%$ тих, хто перехворів через 30 днів і у 13 \% через 60 днів, тоді як інше дослідження виявило біль у грудях у 21\% тих, хто перехворів через 60 днів. Додаткове дослідження з тривалішим спостереженням виявило біль у грудях у 5 \% тих, хто перехворів через 6 місяців. Серцебиття також спостерігалося у 9 \% тих, хто перехворів через 30 днів, у $14 \%$ через 60 днів і у $9 \%$ через 6 місяців $[10,11]$.

Підвищена частота пришвидшеного серцебиття підняла питання про аритмії у тих, хто пережив COVID-19. При гострому COVID-19 повідомлялося як про брадиаритмії (включаючи атріовентрикулярну блокаду високого ступеня), так і про тахіаритмії (включаючи фрібриляцію або тріпотіння передсердь, шлуночкову тахікардію та фрібриляцію шлуночків) [12]; однак вони являють гострі аритмії на фроні гострого захворювання, і хронічність цих нових аритмій є невизначеною. Гострі аритмії частіше зустрічалися у пацієнтів із COVID-19, госпіталізованих до відділень інтенсивної терапії, ніж у пацієнтів загального профрілю, хоча показники, про які повідомляється в літературі, коливались від 18 до $44 \%[13,14]$. Нові електрокардіографрічні зміни та аритмії були виявлені у третини тих, хто пережив нетяжкий COVID-19, шляхом систематичного скринінгу. Цікаво, що при дослідженні частоти аритмій на глобальному рівні повідомлялося про регіональні відмінності в частоті різних аритмій [15].

Найпоширенішою аритмією є фрібриляція передсердь, про яку повідомляють при гострому COVID-19, і часто вона з'являється вперше. Результати одного дослідження показали, що частота фрібриляції передсердь у пацієнтів із гострим COVID-19 подібна до тих, що спостерігаються у пацієнтів із грипом, а наявність фрібриляції передсердь віщує гірший результат [16]. Чи будуть у пацієнтів із нещодавно діагностованою фрібриляцією передсердь 
під час гострого COVID-19 повторюватися епізоди миготливої аритмії та чи збільшується частота більш злоякісних аритмій у тих, хто пережив COVID-19, невідомо. У звітах зафіксовано випадки синдрому постуральної ортостатичної тахікардії як причини серцебиття після одужання від гострого COVID-19, як описано після інших вірусних захворювань [17].

Подовження інтервалу QT було помічено у пацієнтів, госпіталізованих з COVID-19. Деякий ступінь подовження інтервалу QT може виникнути у будь-якого пацієнта з COVID-19, але ця особливість часто посилювалася на початку пандемії, коли для лікування пацієнтів використовували ліки з відомими побічними ефектами, які подовжують інтервал QT, такі, як «Хлорохін», «Гідроксихлорохін» та «Азитроміцин» $[18,19]$.

Повідомляється, що члени сімейства коронавірусів, пов'язані з SARS-CoV-2, SARS-CoV і MERS-CoV, викликають міокардит. Вперше міокардит, пов'язаний із коронавірусом, був зареєстрований у 1980 р. у 43-річного чоловіка з інфекцією верхніх дихальних шляхів, який був госпіталізований у Гельсінкі через тривалу лихоманку, втому та біль у грудях. У пацієнта було діагностовано міокардит, а пізніше в його аналізах крові було помічено значне збільшення специфрічних до коронавірусу антитіл, що вказує на те, що окрім початкової інфекції верхніх дихальних шляхів, коронавіруси можуть викликати міокардит [20].

Перший випадок міокардиту, пов'язаного 3 COVID-19, був зареєстрований у 63-річного чоловіка без серцевих захворювань або гіпертонії в анамнезі, у якого спочатку були симптоми пневмонії. Подальші аналізи крові виявили високий рівень IL-6 і підвищені рівні маркерів ураження міокарда, включаючи тропонін I, міоглобін і N-кінцевий натрійуретичний пептид мозку (NT-BNP). Ехокардіографічно спостерігали збільшення лівого шлуночка, зниження фрракції викиду лівого шлуночка, дифузну дискінезію міокарда та легеневу гіпертензію [21]. Через занепокоєння щодо ушкодження міокарда, спричиненого COVID-19, дослідники почали обстежувати людей, які перенесли COVID-19, за допомогою MPT-серця. Початкові результати досліджень продемонстрували, що як у відібраних осіб (у пацієнтів iз COVID-19 і підвищеним рівнем тропоніну під час госпіталізації), так і у невідібраних осіб (у пацієнтів із безсимптомним, легким, помірним або тяжким перебігом COVID-19) досить висока частота (до 78 \%) пацієнтів мали відхилення від норми, виявлені на МРТ-серця. Ці аномалії включали підвищені значення Т1 (маркер фріброзу або запалення) до 73 \% пацієнтів, підвищення значення Т2 (маркер набряку) до 60 \% пацієнтів при виконанні МРТ-серця протягом 37-71 дня після встановлення діагнозу COVID-19. Ці висновки вказують на персистуючий міокардит та можливої епідемії тривалої серцевої недостатності [22, 23].
На сьогодні міокардит визначається як фрактор ризику підвищення смертності пацієнтів із COVID-19 [24]. Хоча визнання того, що COVID-19 може спричинити гострий міокардит, може сприяти ранній діагностиці та можливому запобіганню смертності, пов'язаної із міокардитом, відсутність розуміння механізму, за допомогою яких SARS-CoV-2 сприяє міокардиту та ураження серця, заважає ретельному лікуванню даного захворювання. Пряме вірусне ураження кардіоміоцитів, гіперзапальний стан і цитокіновий шторм, які зазвичай виникають у тяжких випадках, вважаються основними причинами гострого ураження міокарда та міокардиту.

COVID-19 і серцева недостатність мають міцний зв'язок, який виходить за межі патофрізіології. Перш за все, пандемія COVID-19 вплинула на госпіталізацію пацієнтів із СН: було детально описано скорочення кількості госпіталізацій з приводу даного захворювання, і це може вплинути на смертність від СН. По-друге, серцева недостатність в анамнезі $€$ частим супутнім захворюванням у пацієнтів, госпіталізованих з приводу COVID-19. Це пов'язано 3 вищою смертністю та більшою кількістю ускладнень під час клінічного перебігу. По-третє, поширеність ушкоджень серця після COVID-19, які часто діагностуються лише за допомогою вимірювань біомаркерів. Однак окрім субклінічного ураження міокарда, інфекція SARS-CoV-2 може викликати міокардит із значним зниженням ФВ ЛШ або діастолічну дисфрункцію у більшої кількості пацієнтів. Нарешті, СН може бути короткотривалим або довготривалим наслідком запальної кардіоміопатії COVID-19 із несприятливим наслідком для прогнозу [25].

Усе більше даних показують, що в пацієнтів із COVID-19 найпоширенішими супутніми захворюваннями, асоційованими з гіршим прогнозом і вищим рівнем смертності, є системна гіпертензія, діабет та ожиріння, на тлі яких дисорункція ендотелію $€$ ключовим орактором. В Європейському респіраторному журналі у двох публікаціях про результати досліджень наголошується про ризик тромбозу глибоких вен та гострої легеневої емболії при COVID-19 [26, 27]. Ці дані підтверджують і розширюють попередні спостереження стосовно визначальної ролі дисфункції ендотелію, пов'язаної із SARS-CoV-2, підвищеним ризиком розвитку венозних тромбоемболічних захворювань, системного васкуліту, апоптозу ендотеліальних клітин і запалення в різних органах [28-31]. Відомо також, що SARS-CoV-2 так само як інші інфекційні збудники, унаслідок запальних реакцій може активувати коагулопатію. Відкриття, що щільні гранули тромбоцитів містять поліфросфрати та виділяють їх у разі активації, допомогло виявленню широких зв'язків між імунною системою та коагуляційним каскадом (процесом зсідання крові). Поліфоссрати, вивільняючися з активованих тромбоцитів, пришвидшуть активацію фрактора V,
Вісник медичних і біологічних досліджень Bulletin of Medical and Biological Research
$4(10), 2021$ 
пригнічують антикоагулянтну активність інгібітора тканинного фрактора, сприяють активації фрактора XI тромбіном і синтезу товстіших ниток фрібрину, стійких до фрібринолізу. Запальний есрект цитокінів також призводить до активації ендотеліальних клітин судин і ушкодження ендотелію, що зумовлює протромботичний ефект. Ушкодження судинного ендотелію згодом спричинює тромбоцитопенію, зменшення вмісту природних антикоагулянтів, а також гемостатичну активацію як фенотиповий прояв тромботичної дифузної внутрішньосудинної коагуляції. У разі коагулопатії, асоційованої 3 COVID-19 [32], механізми, які активують коагуляцію при інорікуванні SARS-CoV-2, лишаються невідомими, але, схоже, пов'язані, ймовірніше, із запальними реакціями, а не зі специфічними властивостями вірусу [33].

Нарешті, було показано, що елементи SARSCoV-2 можуть бути виявлені в ендотеліальних клітинах пацієнтів із COVID-19 разом із накопиченням запальних клітин та свідченням загибелі ендотеліальних та запальних клітин [34]. Це вказує на те, що ендотеліїт може спричинюватися SARSCoV-2 та розвиватися в різних органах як прямий наслідок вірусної інфекції та запальної реакції господаря. Згідно з цим виявили, що крім дифузного ушкодження альвеол із периваскулярною Т-клітинною інфрільтрацією та поширеного тромбозу 3 мікроангіопатією характерні особливості судин у пацієнтів із COVID-19 полягали в тяжкому ураженні ендотелію, зумовленому наявністю вірусу в клітинах і ушкодженням клітинних мембран, а також в ангіогенезі [35].

Зрештою, наявність SARS-CoV-2 в ендотеліальних клітинах свідчить про те, що прямі вірусні ефректи, так само як периваскулярне запалення, можуть призвести до ушкодження ендотеліальних клітин. Цілком імовірно, що ендотеліїт, ушкодження ендотелію, дисорунція ендотеліальних клітин і порушення мікроциркуляції у різних судинних руслах відіграють неабияку роль у розвитку загрозливих для життя ускладнень COVID-19, зокрема венозної тромбоемболії та поліорганної недостатності.

Патофрізіологічні механізми цих симптомів до кінця не вивчені, й вони все ще вивчаються, включаючи кардіологічні та серцево-судинні прояви [36]. В одному дослідженні, яке включало 384 госпіталізованих пацієнтів із COVID-19, D-димер, СРБ та рівень феритину нормалізувався протягом двох місяців після виписки. Крім того, на рентгенографрії грудної клітки залишалися аномальні зміни лише у 10 \% цих пацієнтів. Однак стійкі симптоми (втома та задишка) були виявлені у більш ніж двох третин із них, незважаючи на лабораторні та рентгенографрічне поліпшення [37]. Наявні дані свідчать про те, що довгий COVID може бути представлений навіть у пацієнтів із легким перебігом захворювання протя- гом гострої фрази [38]. Повідомлялося, що пацієнти, які перенесли COVID-19, зниження якості життя виявилося у 67 і 63 \% мали знижений фуннціональний статус протягом шести місяців спостереження. Потреба в штучній вентиляції легень, тривалість перебування в реанімації та тривалість перебування в стаціонарі були пов'язані з погіршенням якості життя та фрункціонального стану [39]. Що стосується серцево-судинних симптомів, то причиною ушкодження міокарда може бути фрактор запального каскаду і подальшого фріброзу. Крім того, ступінь і поширення цієї запальної реакції може призвести до несприятливого впливу на шлуночки та до злоякісних аритмій [40]. Можлива роль механізмів запалення в патофрізіології COVID все ще вивчається, але було кілька розроблених гіпотез. Підвищені рівні прозапальних маркерів (наприклад СPБ, IL6 i D-димер) та лімфопенію асоціювали з тривалим перебігом COVID-19 [41]. Недавні дослідження виявило підвищені рівні прозапальних біомаркерів, пов'язаних із судинами, які корелювали з ураженням легенів у пацієнтів із COVID-19, виписаних трьома місяцями раніше [42]. Ці звіти припускають, що невирішене запалення може пояснити частину патофрізіології довгого COVID. Однак для визначення механізмів потрібно більше даних потенційних терапевтичних заходів для нормалізації довгострокового прогнозу пацієнтів. Іншим потенційним механізмом може бути стійка дисрегуляція ренін-ангіотензин-альдостеронової системи (РААС) [43-44].

Поки що дослідження варіювалися від безсимптомних змін до симптомів серцевої недостатності, включаючи пришвидшене серцебиття, стиснення, запаморочення та біль у грудях. Частота 3 них сильно відрізнялися в різних звітах. Крім того, звіти на сьогоднішні мають включали різних пацієнтів, із різними демографічними характеристиками та тяжкістю захворювання.

Крім згаданих проявів, набув розголосу синдром, який отримав назву «синдром постуральної ортостатичної тахікардії» (РОTS). РОTS визначається підвищення частоти серцевих скорочень без зміни артеріального тиску, при переміщенні з положення горизонтального у вертикальне $[45,46]$. Патофрізіологія його невідома, але це може бути пов'язано 3 поствірусним захворюванням [47]. Деякі гіпотези приписують цей синдром до взаємодії між SARSCoV-2 та ACE-2, представленим на нейронах, що призводить до гіпотонії та дизавтономії. Необхідно зазначити, що POTS було запропоновано як можлива причина серцебиття, болю в грудях і запаморочення у пацієнтів із довгим COVID [48-50]. Лікування POTS залишається невідомим. Було запропоновано ранню реабілітація та мультидисциплінарний підхід до пацієнтів, щоб покращити їхній стан. Незалежно від того, яка серцева симптоматика, здоровий спосіб життя та використання бета-блокаторів або івабра- 
дин для лікування тахікардії можуть бути корисними в цьому випадку.

Незважаючи на величезні дослідження серцево-судинних ускладнень COVID-19 та його механізмів, ряд питань, які не мають відповіді, залишаються невирішеними. Однак залишається багато запитань щодо патофрізіологічних механізмів і реальних наслідків візуалізації гострої та післягострої фрази на довгостроковий прогноз. Крім того, варто вивчати короткі та довгострокові наслідки COVID-19 та розробити протоколи скринінгу для виявлення пацієнтів із ризиком серцево-судинних захворювань. Майбутні дослідження також мають визначити цільову групу, терміни скринінгу після первинного одужання від COVID-19 та тести, які допоможуть у сортуванні осіб, які перебувають

\section{СПИСОК ЛІТЕРАТУРИ}

1. Cardiovascular complications in patients with COVID-19: Consequences of viral toxicities and host immune response/ Han Zhu, June-Wha Rhee, Paul Cheng [et.al] // Current Cardiology Reports. - 2020. - No. 32. P. 1-9.

2. Short-term and long-term rates of postacute sequelae of SARS-CoV-2 infection / Destin Groff, Ashley Sun, Anna E. Ssentongo [et al.] // JAMA. - 2021. -No. 4 (10). P. 1-17.

3. Post-acute COVID-19 syndrome / Ani Nalbandian, Kartik Sehgal, Aakriti Gupta [et al.] // Nature Medicine. 2021. - No. 21. - P. 601-615.

4. Post-acute and long-COVID-19 symptoms in patients with mild diseases: a systematic review / Sophie A. M. van Kessel, C. Tim, Olde Hartman, Cornelia H. M. van Jaarsveld // Family Practice. - 2021. - No. 20. - P. 1-9.

5. Shin Jie Yong. Long COVID or post-COVID-19 syndrome: putative pathophysiology, risk factors, and treatments / Shin Jie Yong // Infectious Diseases. -2021. No. 53 (10). - P. 737-754.

6. Weiyi Tan. The cardiovascular burden of coronavirus disease 2019 (COVID-19) with a focus on congenital heart disease/ Weiyi Tan, Jamil Aboulhosn // International Journal of Cardiolog. - 2020. - No. 309. - P. 70-77.

7. Hira Maab. Cardiovascular impact of COVID-19: an array of presentations / Hira Maab, Faryal Mustafa, Syeda Javeria Shabbir // Acta Biomed. - 2021. - No. 92 (2). P. 1-10.

8. Association of cardiac injury with mortality in hospitalized patients with COVID-19 in Wuhan, China / Shaobo Shi, Bo Shen, Tao Liu [et al.] // JAMA Cardiol. 2020. - Vol. 5 (7). - P. 802-810.

9. Potential effects of coronaviruses on the cardiovascular system A review / Mohammad Madjid, Payam Safavi-Naein, Scott D. Solomon [et al.] // JAMA Cardiol. - 2020. - No. 5 (7). - P. 831-840.

10. Follow-up of adults with noncritical COVID-19 two months after symptom onset / Claudia Carvalho-Schneider, Emeline Laurent, Adrien Lemaignen [et al.] // Clin. Microbiol. Infect. - 2021. - No. 27 (2). - P. 258-263.

11. 6-month consequences of COVID-19 in patients discharged from hospital: a cohort study / Chaolin Huang, у групі ризику. Результати досліджень показали, що пацієнти, які одужали від COVID-19, будуть представляти більший ризик для ряду серцевих захворювань, включаючи серцеву недостатність, міокардит, інфаркт міокарда (IM) та аритмії в середньо- та довгостроковій перспективі.

\section{вИСНОВКИ}

Результати аналізу літературних джерел обґрунтовують актуальність дослідження постковідного синдрому у хворих із коморбідним перебігом COVID-19 та серцево-судинною патологією. Визначення ролі COVID-19 у розвитку і прогресуванні серцево-судинних захворювань відкриє шлях для нових підходів до діагностики, стратисрікації, моніторингу, профрілактики та лікування цього захворювання.

Lixue Huang, Yeming Wang [et al.] // Lancet. - 2021. No. 397. - P. 220-232.

12. Cardiac arrhythmias in COVID-19 infection / Stephanie M. Kochav, Ellie Coromilas, Ani Nalbandian [et al.] // Circ. Arrhythm. Electrophysiol. - 2020. - No. 13 (60). - $\mathrm{P}$ e008719.

13. Clinical characteristics of 138 hospitalized patients with 2019 novel Coronavirus-infected pneumonia in Wuhan, China / Dawei Wang, Bo Hu, Chang Hu [et al.] // JAMA. 2020. - No. 323 (11). - P. 1061-1069.

14. Atrial arrhythmias in COVID-19 patients / Chad M. Colon, James G. Barrios, Joe W. Chiles [et al.] // JACC Clin. Electrophysiol. - 2020. - No. 6 (9). - P. 1189-1190.

15. Cardiovascular sequalae in uncomplicated COVID-19 survivors / Zhou, Mi, Wong, Chun-Ka, Un, KaChun [et al.] // PLoS One. - 2021. - No. 16 (2). - Pe0246732

16. Contribution of atrial fibrillation to in-hospital mortality in patients with COVID-19 / Enrico Guido Spinoni, Marco Mennuni, Andrea Rognon [et al.] // Circ. Arrhythm. Electrophysiol. - 2020. - No. 14 (2). - P e009375

17. The "post-COVID" syndrome: How deep is the damage? / P. Garg, U. Arora, A. Kumar, N. Wig // Journal of Medical Virology. - 2020. - No. 93 (2). - P. 673-674.

18. Shin Jie Yong. Long COVID or post-COVID-19 syndrome: putative pathophysiology, risk factors, and treatments / Shin Jie Yong // Infectious Diseases. -2021. No. 53 (10). - P. 737-754.

19. Contribution of atrial fibrillation to in-hospital mortality in patients with COVID-19 / Enrico Guido Spinoni, Marco Mennuni, Andrea Rognon [et al.] // Circ. Arrhythm. Electrophysiol. - 2021. - No. 14 (2). - P e009375.

20. Cardiovascular complications of COVID-19 / Farnaz Farshidfar, Navid Koleini, Hossein Ardehalicorresponding // JCI Insight. - 2021. - No. 6 (13). - P. e148980.

21. First case of COVID 19 complicated with fulminant myocarditis: a case report and insights/ Jia Hui Zeng1, Ying Xia Liu2, Jing Yuan [et al.] // Infection. -2020. - No. 10. - P. 1-5.

22. COVID-19: Myocardial injury in survivors / Daniel S. Knight, Tushar Kotecha, Yousuf Razvi [et al.] // Circulation. - 2020. - No. 142 (11). - P. 1120-1122.

23. 43. Outcomes of cardiovascular magnetic resonance imaging in patients recently recovered from Coronavirus

\section{$4(10), 2021$}


disease 2019 (COVID-19) / Valentina O. Puntmann, M. Ludovica Carerj, Imke Wieters [et al.] // JAMA Cardiol. 2020. -No. 5 (11). - P. 1265-1273.

24. Clinical predictors of mortality due to COVID-19 based on an analysis of data of 150 patients from Wuhan, China / Qiurong Ruan, Kun Yang, Wenxia Wang [et al.] // Intensive Care Med. - 2020. - No. 46 (5). - P. 846-848.

25. COVID-19 and heart failure: From epidemiology during the pandemic to myocardial injury, myocarditis, and heart failure sequelae / Leonardo Italia, Daniela Tomasoni, Stefano Bisegna [et al.] // Front. Cardiovasc. Med. - 2021. - No. 8. - P. 1-14

26. Venous thromboembolism in SARS-CoV-2 patients: only a problem in ventilated ICU patients, or is there more to it? / Maarten Criel, Maarten Falter, Jasmien Jaeken [et al.] // Eur. Respir. J. - 2020. - No. 56 (1). - P. 2001201.

27. Pulmonary embolism in patients with COVID-19 pneumonia/ Florian Bompard, Hippolyte Monnier, Ines Saab [et al.] // Eur. Respir. J. - 2020. -No. 56 (1). - P2001365

28. Pathological evidence of pulmonary thrombotic phenomena in severe COVID-19 / Marisa Dolhnikoff, Amaro Nunes Duarte-Neto, Renata Aparecida de Almeida Monteiro [et al.] // J. Thromb. Haemost. - 2020. - No. 18 (6). - P. 1517-1519.

29. Acute pulmonary embolism and COVID-19 pneumonia: a random association? / Gian Battista Danzi, Marco Loffi, Gianluca Galeazzi [et al.] // Eur. Heart J. 2020. - No. 41 (19). - P. 1858.

30. Pulmonary embolism in patients with COVID-19: Awareness of an increased prevalence / Julien Poissy, Julien Goutay, Morgan Caplan [et al.] // Circulation. - 2020. - No. 142 (2). - P. 184-186.

31. COVID-19 Complicated by acute pulmonary embolism and right-sided heart failure / Waqas Ullah, Rehan Saeed, Usman Sarwar [et al.] // JACC Case Rep. -2020. - No. 2 (9). - P. 1379-1382.

32. COVID-19 and its implications for thrombosis and anticoagulation / Jean M. Connors, Jerrold H. Levy // The American Society of Hematology. - 2020. - No.135 (23). P. 2033-2040.

33. Richard Becker C. COVID-19 update: Covid-19associated coagulopathy / Richard C. Becker // J. Thromb. Thrombolysis. - 2020. - No. 50 (1). -P. 54-67.

34. Endothelial cell infection and endotheliitis in COVID-19 / Zsuzsanna Varga, Andreas J. Flammer, Peter Steiger [et al.] // Lancet. - 2020. -No. 395 (10234). P. 1417-1418.

35. Pulmonary vascular endothelialitis, thrombosis, and angiogenesis in Covid-19 / Maximilian Ackermann 1, Stijn E. Verleden 1, Mark Kuehnel [et al.] //N. Engl. J. Med. 2020. - No. 383 (2). - P. 120-128.

36. Post-acute COVID-19 syndrome and the cardiovascular system: What is known?/ Neal M. Dixit, Austin Churchill, Ali Nsair [et al.] // Am. Heart J. Plus. 2021. - No. 5. - P100025

37. Long-COVID: A cross-sectional study of persisting symptoms, biomarker and imaging abnormalities following hospitalisation for COVID-19 / Swapna Mandal, Joseph Barnett, Simon E. Brill [et al.] // Thorax. - 2020. - No. 76 (4). - P. 396-398.

38. Rubin R. As their numbers grow, COVID-19 "Long haulers" stump experts / Rubin // JAMA. - 2020. - No. 324 (14). - P. 1381-1383.

39. Quality of life, functional status, and persistent symptoms after intensive care of COVID-19 patient / Manuel Taboada, Esther Moreno, Agustín Cariñena [et al.] // Br. J. Anaesth. - 2021. - No. 126 (3). - P e110-e113.

40. Cardiovascular involvement in COVID-19: What sequelae should we expect / Maria Vincenza Polito, Angelo Silverio, Michele Bellino [et al.] // Cardiol. Ther. - 2021. No. 10 (2). - P. 377-396.

41. Inflammatory profiles and clinical features of Coronavirus 2019 survivors 3 months after discharge in Wuhan, China / Mei Zhou, Zhengrong Yin, Juanjuan Xu [et al.] // J. Infect. Dis. - 2021. - No. 224 (9). - P. 1473-1488.

42. Interactions of coronaviruses with ACE2, angiotensin $\mathrm{II}$, and RAS inhibitors - lessons from available evidence and insights into COVID-19 / Hisashi Kai, Mamiko Kai // Hypertension Research Volume. - 2020. - No. 43. P. 648-654.

43. SARS-CoV-2 cell entry depends on ACE2 and TMPRSS2 and is blocked by a clinically proven protease inhibitor / Markus Hoffmann, Hannah Kleine-Weber, Simon Schroeder [et al.] // Cell. - 2020. No. 181 (2). - P. 271-280.

44. An equally important protease as ACE2 in the pathogenicity of SARS-CoV-2 infection / Malvinder S. Parmar // Mayo Clin. Proc. - 2020. - No. 96 (11). - P. 27482752

45. Long-haul post-COVID-19 symptoms presenting as a variant of postural orthostatic tachycardia syndrome: The Swedish experience / Madeleine Johansson, Marcus Ståhlberg, Michael Runold [et al.] // JACC Case Rep. 2021. - No. 3 (4). - P. 573-580.

46. Clinical sequelae of COVID-19 survivors in Wuhan, China: A single-centre longitudinal study / Qiutang Xiong, Ming Xu, Jiao Li [et al.] // Clin. Microbiol. Infect. - 2021. No. 27 (1). - P. 89-95.

47. Postural orthostatic tachycardia syndrome: JACC focus seminar / Meredith Bryarly, Lauren T. Phillips, Qi Fu [et al.] // J. Am. Coll. Cardiol. - 2019. -No. 73 (10). P. 1207-1228.

48. Fedorowski A. Postural orthostatic tachycardia syndrome: clinical presentation, aetiology and management / A. Fedorowski // J. Intern. Med. - 2019. - No. 285 (4). P. 352-366.

49. David Goldstein S. The possible association between COVID-19 and postural tachycardia syndrome / David S. Goldstein // Heart Rhythm. - 2021. -No. 18 (4). - P. 508-509.

50. New-onset postural orthostatic tachycardia syndrome following Coronavirus disease 2019 infection / Khalil Kanjwal, Sameer Jamal, Asim Kichloo [et al.] // J. Innov. Card Rhythm Manag. - 2020. - No. 11 (11). P. 4302-4304. 


\section{REFERENCES}

1. Han Zhu, June-Wha Rhee, Paul Cheng. Cardiovascular complications in patients with COVID-19: Consequences of viral toxicities and host immune respon. Current Cardiology Reports. 2020;32: 1-9.

2. Destin Groff, Ashley Sun, Anna E. Sentongo. Shortterm and long-term rates of postacute sequelae of SARSCoV-2 Infection. JAMA. 2021;4(10): 1-17.

3. Ani Nalbandian, Kartik Sehgal, Aakriti Gupta. Postacute COVID-19 syndrome. Nature Medicine. 2021;21: 601-5.

4. Sophie A. M. van Kessel, Tim C. Olde Hartman, Cornelia H. M. van Jaarsveld Post-acute and long-COVID-19 symptoms in patients with mild diseases: a systematic review. Family Practice. 2021;20: 1-9. DOI:10.1093/fampra/ cmab076

5. Shin Jie Yong. Long COVID or post-COVID-19 syndrome: putative pathophysiology, risk factors, and treatments. Infectious Diseases. 2021;53(10); 737-54.

6. Weiyi Tan, Jamil Aboulhosn. The cardiovascular burden of coronavirus disease 2019 (COVID-19) with a focus on congenital heart disease. International Journal of Cardiolog. 2020;309: 70-7.

7. Hira Maab, Faryal Mustafa, Syeda Javeria Shabbir. Cardiovascular impact of COVID-19: an array of presentations. Acta Biomed. 2021;92(2): 1-10. DOI: $10.23750 / a b m . v 92 \mathrm{i} 2.10299$

8. Shaobo Shi, Bo Shen, Tao Liu. Association of cardiac injury with mortality in hospitalized patients with COVID-19 in Wuhan, China. JAMA Cardiol. 2020;5(7): 802-10. DOI:10.1001/jamacardio.2020.0950

9. Mohammad Madjid, Payam Safavi-Naein, Scott D. Solomon. Potential effects of Coronaviruses on the cardiovascular system. A review. JAMA Cardiol. 2021;5(7): 831-40. DOI:10.1001/jamacardio.2020.1286

10. Claudia Carvalho-Schneider, Emeline Laurent, Adrien Lemaignen. Follow-up of adults with noncritical COVID-19 two months after symptom onset. Clin. Microbiol. Infect. 20211;27(2): 258-63.

11. Chaolin Huang, Lixue Huang, Yeming Wang. 6-month consequences of COVID-19 in patients discharged from hospital: a cohort study. Lancet. 2021;397: 220-32. DOI: 10.1016/S0140-6736(20)32656-8.

12. Stephanie M. Kochav, Ellie Coromilas, Ani Nalbandian Cardiac. Arrhythmias in COVID-19 Infection. Circ Arrhythm Electrophysio. 2020;13(60): e008719

13. Dawei Wang, Bo $\mathrm{Hu}$, Chang $\mathrm{Hu}$ Clinical. Characteristics of 138 hospitalized patients with 2019 novel coronavirus-infected pneumonia in Wuhan, China. JAMA. 2021;323(11): 1061-9. DOI:10.1001/jama.2020.1585

14. Chad M. Colon, James G. Barrios, Joe W. Chiles. Atrial arrhythmias in COVID-19 patients. JACC Clin. Electrophysiol. 2020;6(9): 1189-90.

15. Zhou, Mi, Wong. Chun-Ka, Un, Ka-Chun. Cardiovascular sequalae in uncomplicated COVID-19 survivors. PLoS One. 2021;16(2): e0246732.

16. Enrico Guido Spinoni, Marco Mennuni, Andrea Rognon. Contribution of atrial aibrillation to in-hospital mortality in patients with COVID-19. Circ Arrhythm Electrophysiol. 2021;14(2): e009375. DOI: 10.1161/ CIRCEP.120.009375

17. Blitshteyn S, Whitelaw S. Postural orthostatic tachycardia syndrome (POTS) and other autonomic disorders after COVID-19 infection: a case series of 20 patients. Immunol Res. 2021;69: 205-11.

18. Thomas F O'Connell, Christopher J Bradley, Amr E Abbas. Hydroxychloroquine/azithromycin therapy and QT prolongation in hospitalized patients with COVID-19. JACC Clin Electrophysiol. 2021;7(1): 16-25.

19. Ohad Oren, Eric H. Yang, Ty J. Gluckman. Use of chloroquine and hydroxychloroquine in COVID-19 and cardiovascular implications. Circ Arrhythm Electrophysiol. 2020;13(6): e008688.

20. Farnaz Farshidfar, Navid Koleini, Hossein Ardehalicorresponding. Cardiovascular complications of COVID-19. JCI Insight. 2021;6(13): e148980.

21. Jia Hui Zeng1, Ying Xia Liu2, Jing Yuan. First case of COVID 19 complicated with fulminant myocarditis: a case report and insights.Infection. 2020;10: 1-5. DOI: 10.1007/ s15010-020-01424-5

22. Daniel S. Knight, Tushar Kotecha, Yousuf Razvi. COVID-19: Myocardial injury in survivors. Circulation. 2020;142(11): 1120-2. DOI: 10.1161/ CIRCULATIONAHA.120.049252

23. Valentina O Puntmann, M Ludovica Carerj, Imke Wieters. Outcomes of cardiovascular magnetic resonance imaging in patients recently recovered from Coronavirus disease 2019 (COVID-19). JAMA Cardiol. 2020;5(11): 1265-73. DOI: 10.1001/jamacardio.2020.3557.

24. Qiurong Ruan, Kun Yang, Wenxia Wang. Clinical predictors of mortality due to COVID-19 based on an analysis of data of 150 patients from Wuhan, China. Intensive Care Med. 2020;46(5): 846-8. DOI: 10.1007/ s00134-020-05991-x.

25. Leonardo Italia, Daniela Tomasoni, Stefano Bisegna, Edoardo Pancald. COVID-19 and heart failure: From epidemiology during the pandemic to myocardial injury, myocarditis, and heart failure sequelae. Front. Cardiovasc. 2021;8: 1-14.

26. Maarten Criel, Maarten Falter, Jasmien Jaeken. Venous thromboembolism in SARS-CoV-2 patients: only a problem in ventilated ICU patients, or is there more to it. Eur Respir. 2020;56(1): 2001201. DOI: 10.1183/13993003.01201-2020

27. Florian Bompard, Hippolyte Monnier, Ines Saab. Pulmonary embolism in patients with COVID-19 pneumonia. Eur. Respir. J. 2020;56(1): 2001365. DOI: 10.1183/13993003.01365-2020

28. Marisa Dolhnikoff, Amaro Nunes Duarte-Neto, Renata Aparecida de Almeida Monteiro. Pathological evidence of pulmonary thrombotic phenomena in severe COVID-19. J Thromb Haemost. 2020;18(6): 1517-9.

29. Gian Battista Danzi, Marco Loffi, Gianluca Galeazzi. Acute pulmonary embolism and COVID-19 pneumonia: a random association? Eur Heart J. 2020;41(19): 1858

30. Julien Poissy, Julien Goutay, Morgan Caplan. Pulmonary embolism in patients with COVID-19: Awareness of an increased prevalence. Circulation.2020;142(2): 184-6.

31. Waqas Ullah, Rehan Saeed, Usman Sarwar. COVID-19 Complicated by acute pulmonary embolism and right-sided heart failure. JACC Case Rep. 2020; 2(9): 137982.

32. Jean M. Connors, Jerrold H. Levy. COVID-19 and its implications for thrombosis and anticoagulation. The American Society of Hematology. 2020;135(23): 2033-40. 
33. Richard C Becker. COVID-19 update: Covid19-associated coagulopathy. J Thromb Thrombolysis. 2020;50(1): 54-67.

34. Zsuzsanna Varga, Andreas J Flammer, Peter Steiger. Endothelial cell infection and endotheliitis in COVID-19. Lancet. 2020;395(10234): 1417-8.

35. Maximilian Ackermann, Stijn E Verleden, Mark Kuehnel. Pulmonary vascular endothelialitis, thrombosis, and angiogenesis in Covid-19. N Engl J Med. 2020;383(2): 120-8.

36. Neal M. Dixit, Austin Churchill \& Ali Nsair. Post-acute COVID-19 syndrome and the cardiovascular system: What is known? Am Heart J Plus. 2021;5: 100025.

37. Swapna Mandal, Joseph Barnett, Simon E Brill. Long-COVID: A cross-sectional study of persisting symptoms, biomarker and imaging abnormalities following hospitalisation for COVID-19. Thorax. 2020;76(4): 396-8.

38. Rita Rubin. As their numbers grow, COVID-19 "Long Haulers" Stump Experts. JAMA. 2020;324(14): 1381-83.

39. Manuel Taboada, Esther Moreno, Agustín Cariñena. Quality of life, functional status, and persistent symptoms after intensive care of COVID-19 patient. $\mathrm{Br} \mathrm{J}$ Anaesth. 2021;126(3): e110-3.

40. Maria Vincenza Polito, Angelo Silverio, Michele Bellino. Cardiovascular involvement in COVID-19: What sequelae should we expect. Cardiol Ther. 2021;10(2): 377396.

41. Mei Zhou, Zhengrong Yin, Juanjuan Xu. Inflammatory profiles and clinical features of Coronavirus 2019 survivors 3 months after discharge in Wuhan, China. J Infect Dis. 2021;224(9): 1473-88.
42. Hisashi Kai, Mamiko Kai. Interactions of coronaviruses with ACE2, angiotensin II, and RAS inhibitors - xlessons from available evidence and insights into COVID-19.Hypertension Research volume. 2020;43: 64854.

43. Markus Hoffmann, Hannah Kleine-Weber, Simon Schroeder. SARS-CoV-2 cell entry depends on ACE2 and TMPRSS2 and is blocked by a clinically proven protease inhibitor. Cell. 2020;181(2): 271-80.

44. Malvinder S. Parmar. An equally important protease as ACE2 in the pathogenicity of SARS-CoV-2 infection. Mayo Clin Proc. 2020;96(11): 2748-52.

45. Madeleine Johansson, Marcus Stahlberg, Michael Runold. Long-haul post-COVID-19 symptoms presenting as a variant of postural orthostatic tachycardia syndrome: The Swedish experience. JACC Case Rep. 2021;3(4): 573-80.

46. Qiutang Xiong, Ming $\mathrm{Xu}$, Jiao Li. Clinical sequelae of COVID-19 survivors in Wuhan, China: a single-centre longitudinal study. Clin Microbiol Infect. 2021;27(1): 89-95.

47. Meredith Bryarly, Lauren T Phillips, Qi Fu. Postural orthostatic tachycardia syndrome: JACC Focus Seminar. J Am Coll Cardiol. 2019;73(10): 1207-28

48. Fedorowski A. Postural orthostatic tachycardia syndrome: clinical presentation, aetiology and management. J Intern Med. 2019;285(4): 352-66.

49. David S Goldstein. The possible association between COVID-19 and postural tachycardia syndrome. Heart Rhythm. 2021;18(4): 508-9.

50. Khalil Kanjwal, Sameer Jamal, Asim Kichloo. Newonset postural orthostatic tachycardia syndrome following coronavirus disease 2019 infection. J Innov Card Rhythm Manag. 2020;11(11): 4302-4 